\title{
THE RETOPIAN IMAGINATION
}

\author{
Dirk Hoyer \\ (Tallinn University Baltic Film Media Arts and Communication School, Estonia)
}

\begin{abstract}
Can the current attitudes toward utopia be described as hollow space in the Blochian sense? The political debate is dominated by apocalyptic imagination which fuels populist movements but ultimately it does not have any emancipatory potential. Contemporary reflection on utopia can be either defined by a outopian attitude that is critical towards the status quo but sees alternative arrangements as no-places or as a contemplative utopia, that recognizes the need for utopian visions but cannot identify any political agency. Activism without utopian mental picture often disintegrates for lack of a unified goal and therefore cannot live up to its transformative potential. Retopia, the fourth attitude towards utopia could refocus the eutopian impulse and counter the apocalyptic imagination with a radical imagination that is based on the encouragement of political action. Politics is a confidence game and action inspired by retopian mental pictures could create a sense of an opening in the There is No Alternative doctrine that dominates the political sphere..
\end{abstract}

KEYWORDS: outopia/eutopia, retopia, action, imagination, political agency

\section{LA IMAGINACIÓN RETÓPICA}

\section{RESUMEN}

¿Pueden describirse las actitudes actuales hacia la utopía como un espacio vacío en el sentido Blochiano? El debate político está dominado por la imaginación apocalíptica que alimenta los movimientos populistas pero que, en última instancia, no tiene ningún potencial emancipatorio. La reflexión contemporánea sobre la utopía puede definirse por una actitud outópica, crítica hacia el status quo, pero que ve las propuestas alternativas como no-lugares o como una utopía contemplativa, que reconoce la necesidad de visiones utópicas pero no puede identificar a ninguna agencia política. El activismo sin imagen mental utópica a menudo se desintegra por falta de un objetivo unificado y, por lo tanto, no puede estar a la altura de su potencial transformador. Retopía, la cuarta actitud hacia la utopía podría reenfocar el impulso eutopista y contrarrestar la imaginación apocalíptica con una imaginación radical que se basa en el estímulo de la acción política. La política es un juego de confianza y la 
acción inspirada en las imágenes mentales retópicas podría crear una sensación de apertura en la doctrina de No bay alternativa que domina la esfera política.

PALABRAS CLAVE: outopía/eutopía, retopía, acción, imaginación, agencia política

In a conversation with Jürgen Rühle in 1964, Ernst Bloch described his epoch as hollow space (Hoblraum). Bloch saw a few sparkles in this hollow space but ultimately there was a vacuum of ideas that people were aware of. At best the prevailing feeling of emptiness could be described as boredom. At worst the Zeitgeist could be characterized as "despair that will mutate into nihilism"1.

Four years after the interview the 1968 student protests broke out that embodied the spark, the desire for a different society. With hindsight, the changes on the socio-economic organization of Western society that followed were modest, the upheaval evaporated and most of its protagonists successfully integrated into the status quo. In the aftermath of the 2008 crisis the critique of the politico-economic model resurfaced hence in less radical ways. But Bloch's concern remains topical: are there still any sparkles left in the Hohlraum? And is the Hohlraum still a Hohlraum?

By bracketing out the letter $\mathrm{h}$ in the middle of the German word Hoblraum, it becomes a Holraum, as space out of which you take things. Contemporary society could be thus more appropriately described by Ho(b)Iraum, a hollow space out of which people try to take things out for their personal benefit. A sort of "takeaway lacuna". This Ho(b)lraum-society has even less sparkles left than Bloch's Hohlraum because nobody is willing to animate the hollow space as the only concern is to optimize the individual profit. The society is enclosed in its present state and excludes any form of collective imagination.

In the individualistic absolute present, the future has become an uncomfortable dimension that is mostly perceived in apocalyptic terms or has entered the abyss of absence. Bloch himself warns that "without the dimension of the future, conceivable for us as an adequate future, no empirical being will endure long"" . He underlines the utopian dimension of this by explaining that:

... in ages of growing darkness at least a horror vacui, and in ages of increasing enlightenment always a plus ultra, shows that Utopian

\footnotetext{
${ }^{1}$ Ernst Bloch, Tendenz-Latenz-Utopie (Frankfurt: Suhrkamp, 1978): 327-349.

${ }^{2}$ Ernst Bloch, A Philosophy of the Future (New York: Herder and Herder, 1970): 92.
} 
consciousness is alive. All the worse then, if a society that will no longer be reconciled in an abstract-utopian manner, but demands the way to the thing itself, errs on the way-and errs dangerously ${ }^{3}$.

The desire for change has manifested itself in protest movements like the Indignados or Occupy and on the reactionary side in the Tea Party movement, Trumpism or in the rise of European right-wing parties. The question is why the movements on the left have disintegrated so quickly while the movements on the right have been integrated into the political decision making process. What does this integration reveal about the political imagination? The Tea Party and its European spiritual cousins are articulating some form of a glorification of the (lost) past, which according to Goodwin and Tyler "renders the thinker impotent with respect to both present or future" ". Hence their agenda of change has no emancipatory potential for the future. But this does not make these reactionary movements any less attractive. As Lilla points out the reactionaries have discovered that nostalgia can be a powerful motivator (especially in an aging society) ${ }^{5}$. While Bloch underlined that hope is superior to fear, Lilla maintains that nostalgia is "perhaps even more powerful than hope" because hopes can be disappointed whereas nostalgia is irrefutable ${ }^{6}$.

On the left, the absence of a future image and possibly the too loose forms of organization have led to a quick disintegration and the potential of agency has vanished along with it. But this does not mean that the only alternative is nihilism or defeatism. Levitas writes that the "problem of agency does not arise because the desire for an alternative has weakened, but because hope depends on the transition appearing to be practically possible"'.

As the importance of the factor of hope has been already conceptualized by Bloch, the realm of the possible has to be the focus of any emancipatory movement. Without a clear conceptualization (that remains flexible enough to be adjusted to changes in the social construct called society) of the possible, without an articulation of utopian mental images, political agency will ultimately vaporize and revert to criticism that helplessly mourns the hollow space without being able to imagine an alternative.

${ }^{3}$ Ibidem: 92.

${ }^{4}$ Barbara Goodwin and Keith Tyler, The Politics of Utopia: A Study in Theory and Practice (London: Hutchinson, 1981): 23.

${ }^{5}$ Mark Lilla, The Shipwrecked Mind, On Political Reaction (New York: New York Review Books, 2016).

${ }^{6}$ Ibidem: xiv.

${ }^{7}$ Ruth Levitas, The Concept of Utopia (Witney: Peter Lang, 2011): 228. 


\section{THE CONTEMPORARY ATTITUDES TO UTOPIA}

Judt attempts to answer the question of why it is so difficult to imagine a different society by pointing at the lack of reference. He states:

Our disability is discursive: we simply do not know how to talk about these things anymore. For the last thirty years, when asking ourselves whether we support a policy, a proposal or an initiative, we have restricted ourselves to issues of profit and loss- economic questions in the narrowest sense. But this is not an instinctive human condition: it is an acquired taste 8 .

The acquired taste of narrowed down economic thinking has also downsized the expectation towards possible social and political change unless the ideas are quantifiable in profit-loss categories. The contemporary approach to change, even more to utopian mental images of change is dominated by a skepticism that is cemented in the dogma: There is no alternative (TINA) to the existing social and economic arrangements. Among contemporary thinkers three basic attitudes in relation to social alternatives, possible reality-transcending political concepts and their manifestation through a utopian mental image can be described: contemporary outopia, contemplative utopia and activism without utopian mental picture. A classification could thus be:

1) contemporary outopia (Fisher, Berardi, Augé, Hardt \& Negri, Agamben): the attitude towards social alternatives is critical because the contemporary outopia is implicitly based on the premise that social change is not possible in an allenglobing system. The world is more likely to change for worse, become a nonplace, an outopia and the political imagination is forever locked in the present framework. There are no discernible utopian mental images to be found in the contemporary outopia and the general attitude is in most cases fatalistic. The TINA premise (There Is No Alternative) is largely accepted.

2) contemplative utopia (Jameson, Weiss, Jacoby, Thompson): the attitude towards social alternatives is generally positive, the need for utopian transformation is recognized and social change is considered to be theoretically possible however no concrete agency is articulated or even identified. The general positive function of Utopia as a reality transcending political concept is recognized however often with an ambiguous angle because of the historical failures of certain utopian concepts. The utopian mental image for the contemplative utopia would be a map, which is drawn with the intention to frame the complex realities. The need to draw a map indicates also a general uncertainty about the direction and shape of possible political change.

\footnotetext{
8 Tony Judt, Ill Fares the Land (London: Penguin, 2010): 34.
} 
3) activism without utopian mental picture (Graeber, Haiven and Khasnabish): the attitude towards social alternatives is positive, activism is recognized as a way of changing the framework of society, theory is important but action is primordial. There are reality transcending political concepts but they are largely rooted in anarchism (or anarcho-syndicalism) and feminism in some rarer cases (none of the above-mentioned authors) still from Marxism. The reality transcending concepts generally do not contain a concrete image of utopian futures but are more ideological orientation points, which conceptually frame the political struggle.

This classification makes clear that agency and utopia are largely disconnected from each other in contemporary perception of the possibilities of social change. For any social transformation to be conceivable the two domains of agency and utopian thinking would have to be connected to each other. Hence a fourth category, an aspirational category, is needed in order to connect agency and utopian mental image. A reconstructive utopia in the sense Mumford (1922) defined it "a reconstituted environment that is better adapted to the nature and aims of the human beings who


nature is not only problematic but also superfluous, hence the retopia is a eutopia (so the aim is to improve the social arrangements) that explicitly grounds the utopian in the local environment and not in abstract universals. The retopia can be thus classified as the fourth basic attitude towards utopia:

4) retopia: the attitude towards social change is positive, activism is recognized as a way of changing the framework of society. Agency is at the basis of political change. This agency is grounded in a utopian mental image that is open to change but serves as a catalyst and compass that will avoid the segregation and disintegration of the political struggle. Retopia is a eutopia with the claim to be put into practice through social experimentation on the ground (with an open outcome).

The retopia has with Wright's real utopia in common that it is" grounded in the belief that what is pragmatically possible is not fixed independently of our imaginations, but is itself shaped by our visions." 10 Selffulfilling prophecies are powerful forces in history. This optimism refutes the reigning fatalism of many contemporary thinkers. It is explicitly based on the possibilities of political agency and is an encouragement to leave the TINA dogma behind. The key factors are: imagination, will and action.

Out of the four different types of utopianism, the contemporary outopia, the contemplative utopia, activism without utopian mental picture and the retopia, the later type is

\footnotetext{
${ }^{9}$ Lewis Mumford, The Story of Utopias (New York: Boni and Liveright, 1922): 14.

${ }^{10}$ Eric Olin Wright, Envisioning Real Utopias (London: Verso, 2010): 6.
} 
the only type of utopianism having the potential to animate political agency for more than just a season or two of protest. The retopia, in its focus on agency is countering the passivity of the "idiots" (in Arendt's sense) and in its open-ness it is a resistance to any kind of political fundamentalisms.

Nicole Pohl's definition of Utopia is also valid for retopia. Pohl argues that:

Utopia is and must be flexible, heterogeneous, local yet global, located at the blurring boundaries of the aesthetic, ethical, juridical and political. Utopia demonstrates the continual exploration of that which is possible ${ }^{11}$.

In the context of retopia, "blurring boundaries" does not mean diffused focus but openness to other priorities than disciplinary borders and narrow knowledge generation.

\section{APOCALYPTIC VERSUS RADICAL IMAGINATION}

The possible new "islands of retopia" can be located not in the future or in a remote place but in the middle of Western societies. Local social experiments can generate a new form of activism that is not based on abstract critique but on selfgenerated knowledge about social alternatives. Each local social experiment can agree on a common value system and the plurality of experiments that are all locally rooted can also provide a plurality of different experiences. TINA becomes TAMA (There are Many Alternatives). All the know-how and all the locations that are left-overs of the capitalist transformation binge can be bundled to generate new forms of social organization. Therefore, retopia is based on the importance of a vision of different futures, on the power of imagination, on the volition and on the constitutive power of action.

As Bloch pointed out the connection between action and utopia:

Action will release available transitional tendencies into active freedom only if the Utopian goal is clearly visible, unadulterated and unrenounced. Even though the Utopias have at best promised their still so palpable optima, but have promised them as objectively and really possible ${ }^{12}$.

In that understanding, Utopia and political action combined are the possible remedies against the nostalgia that permeated among the reactionary political parties in Europe and the United States. The right-wing populism is explicitly based on an apocalyptic imagination. As Lilla argues:

\footnotetext{
${ }^{11}$ Nicole Pohl, "Utopia Matters", Spaces of Utopia, 7 (2009): 1-14, 10.

12 Bloch A Philosophy of the Future: 92.
} 
For the apocalyptic imagination, the present, not the past, is a foreign country. That is why it is so inclined to dream of a second event that will blow open the doors of paradise. Its attention is fixed on the horizon as it awaits the Messiah, the Revolution, the Leader, or the end of time itself ${ }^{13}$.

As this definition shows, the apocalyptic imagination is not only limited to religious or reactionary groups but also to left-wing radicals who advocate a revolution. The implicit dimension in this perception of political change is a catastrophe of a significant scale. The absolute scale of change (and the implied human casualties in the process) that the apocalyptic imagination is based on are an echo of some of the most terrible political crimes of the $20^{\text {th }}$ century. Despite (or because of) the epic scale of the anticipated catastrophe, in the apocalyptic imagination the agency is very limited. The alternative to apocalyptic imagination is radical imagination.

The concept of radical imagination by Haiven and Khasnabish highlights the importance of collective imagination. Radical imagination is defined as an "aspirational term" which aims at imagining "the world, life and social institutions" with the explicit recognition "that the world can and should be changed"14. Haiven and Khasnabish underline that:

... the radical imagination is not just about dreaming about different futures. It's about bringing those possible futures 'back' to work on the present, to inspire action and new forms of solidarity today. Likewise, the radical imagination is about drawing on the past, telling different stories about how the world came to be the way it is, and remembering the power and importance of past struggles and the way their spirits live on in the present ${ }^{15}$.

The focus of radical imagination is "to imagine and make common cause with the experiences of other people" and "to build solidarity across boundaries and borders, real or imagined" "with the explicit intention to undermine the existing power structures. The collective dimension is thus not only an ethical dimension, but has also the dimension of enlarging the scope, as Haiven and Khasnabish explain:

...we understand the imagination as not merely the 'private property' of the individual. Through shared experiences, language, stories, ideas, art and theory we share part of our imagination. We create, with those around us, multiple, overlapping, contradictory and coexistent imaginary landscapes, horizons of common possibility and shared understanding ${ }^{17}$.

${ }^{13}$ Lilla, The Shipwrecked Mind: 137.

${ }^{14}$ Max Haiven and Alex Khasnabish, The Radical Imagination: Social Movement Research in the Age of Austerity (London: Zed, 2014): 3.

15 Ibidem: 3.

16 Ibidem: 3.

${ }^{17}$ Haiven and Khasnabish, The Radical Imagination: 3. 
Thus, solidarity and imagination are intertwined in the form of a "shared landscape and a common resource that both informs our actions and relationships and is, in turn, shaped by our actions and relationships"18. So in radical imagination the creative force of the individual is enhanced through the creation of shared imaginaries.

\section{ACTION AT THE POINT OF BIFURCATION}

As the lasting impact of neoliberalism shows, in politics, imagination (and the scope of the imagination) has a transformative potential. As Graeber explains, politics "is the art of persuasion; the political is that dimension of social life in which things really do become true if enough people believe them." ${ }^{.19}$ In reverse this means that if nobody believes in change because there is not enough imagination then stagnation becomes the status quo. In Graeber's understanding politics is a confidence game that is "very similar to magic". As Graeber illustrates the political process:

If you managed to convince everyone on earth that you can breathe under water, it won't make a difference: if you try it you will still drown. On the other hand, if you could convince everyone in the entire world that you were the King of France, then you would actually be the King of France. (In fact, it would probably work just to convince a substantial portion of the French civil service and military) ${ }^{20}$.

This shows the power of confidence games and ideas in the political process. While the political reality is obviously more complex, in its essence "political power has to be constantly recreated persuading others to recognize one's power" ${ }^{\prime 2}$. That means any contemplative attitude towards politics is a way of renouncing political power. Persuasion and action are the fundaments of political power. As Hannah Arendt clarifies "men constantly create their own, self-made conditions" 22. So, according to Arendt, "since action is the political activity par excellence, natality, not mortality, may be the central category of political, as distinguished from metaphysical thought" ${ }^{23}$. Action is the domain of the political and inactivity or passivity merely leads to the domestication of the citizens. Therefore, a figure like Bartleby can never be political because he opts for a fatalistic retreat ${ }^{24}$. As Arendt observed already in the 1950s, a tendency towards excluding action was a way of standardizing societies and producing conformity. Arendt writes:

\footnotetext{
18 Ibidem: 226.

${ }^{19}$ David Graeber, Debt: The first 500 Years (New York: Melville House, 2012): 322.

${ }^{20}$ David Graeber, Revolutions in Reverse, Essays on Politics, Violence, Art and Imagination (New York: Minor Compositions, 2011): 94.

${ }^{21}$ Ibidem: 94.

${ }^{22}$ Hannah Arendt, The Human Condition (Chicago: The University of Chicago Press, 1998): 9.

${ }^{23}$ Ibidem: 40.

${ }^{24}$ For more on the difference between Bartleby and utopian imagination, see Dirk Hoyer, "The Possibility of Another Island: Utopian Discourse in the Age of Dystopia", Antae 4-1 (2017): 25-37.
} 
It is decisive that society, on all its levels, excludes the possibility of action, which formerly was excluded from the household. Instead, society expects from each of its members a certain kind of behavior, imposing innumerable and various rules, all of which tend to 'normalize' its members, to make them behave, to exclude spontaneous action or outstanding achievement ${ }^{25}$.

As action can have unpredictable consequences, political control means replacing action with behavior, which means normalized activity in a regular predictable frame. Arendt sees that this conformism, "the assumption that men behave and do not act with respect to each other, that lies at the root of the modern science of economics" 26 . So behavior is the category of the homo economicus, the formatted homo sapiens.

With the rise of neo-liberalism this homo economicus was distilled even further because the domain of the imagination was colonized in the same way as the domain of action. Graeber (2011) remarks that "the neoliberal project really has been stripped down to what was always its essence: not an economic project at all, but a political project, designed to devastate the imagination, and willing",27.

But action, imagination and willing are closely connected, not only but also in the political process. Arendt lays the connection open by tracing back the etymological roots of action:

Greek and Latin, unlike the modern languages, contain two altogether different and yet interrelated words with which to designate the verb "to act". To the two Greek verbs archein ("to begin", "to lead", finally "to rule") and prattein ("to pass through", "to achieve", "to finish") correspond the two Latin verbs agree ("to set in motion", "to lead") and gerere (whose original meaning is "to bear"). Here it seems as though each action were divided in two parts, the beginning made by a single person and the achievement in which many join by "bearing" and "finishing" the enterprise, by seeing it through $^{28}$.

Action thus means to begin and then convince others to join. In an environment of conformism every beginning is met with rejection because it transcends the frame of normalized regular behavior and ultimately challenges the status quo. Thus, action is not only at the root of politics but also at the root of utopia. Utopias "boost human activity" and "deliberate collective action ${ }^{29}$, as Levitas underlines. Action is the entry ticket into the confidence game of political

\footnotetext{
25 Arendt, The Human Condition: 40.

${ }^{26}$ Ibidem: 41.

${ }^{27}$ Graeber, Revolutions in Reverse: 5-6.

28 Arendt, The Human Condition: 189.

${ }^{29}$ Levitas, The Concept of Utopia: 196.
} 
transformation. But action in the framework of enclosure (of political imagination) and in the absence of a utopian mental picture risks to be co-opted by the status quo. Immanuel Wallerstein claims that there are at least two alternatives:

If we are making a fundamental historical choice in the next fifty years, what is it between? Clearly, our choice is between a system (analogous to the present one in some fundamentals) in which some have significantly greater privileges than others, and one that is relatively democratic and egalitarian. With much, much more value produced, the difference between the top stratum and the rest could be and has been far greater than in the other historical systems, even if it is true that the top stratum of the present system has included a larger percentage of the system's overall population than that of preceding historical systems ${ }^{30}$.

Wallerstein developed in Utopistics a hybrid between historic determinism and individual or collective agency. In the context of his world systems theory, Wallerstein explains that the capitalist world economy (which started roughly at the time of Thomas More's Utopia) is coming to an end and that we are living in a time of transition to a yet unknown new world system. In these times of transitional TimeSpace, or points of bifurcation as Wallerstein calls them, the influence of the free will factor is far higher than in the times of the ongoing life of the world system. For Wallerstein, the French and the Russian Revolution ultimately did not result in any world historical change because they happened at the wrong moment, when the world system was not yet at the point of transition. Wallerstein explains that:

... when systems are functioning normally, structural determinism outweighs individual and group free will. But in times of crisis and transition, the freewill factor becomes central. The world of 2050 will be what we make it. This leaves full rein for our agency, for our commitment, and for our moral judgment. It also means that this period will be a time of terrible political struggle, because the stakes are much higher than in so-called normal times ${ }^{31}$.

\section{FUTURE REIMAGINED?}

The places for experimenting with what Wallerstein calls the "relatively democratic and egalitarian" alternative might be opening up in the places that have lost their value (in the sense of capitalist value generation) like some areas in Southern Europe or deindustrialized cities in the US such as Detroit. The ruins of capitalism might provide the space for developing forms of living that are guided neither by neoliberal dogmatism nor by apocalyptic imagination. The question is whether places

\footnotetext{
${ }^{30}$ Immanuel Wallerstein, Utopistics, Or, Historical Choices of the Twenty-first Century (New York: The New Press, 1998): 69.

31 Ibidem: 64.
} 
like Detroit become the avant-garde of new social arrangements, if the city gets regentrified or if the social fragmentation engendered by the economic decline leads to a hostile environment? The need for laboratories in the research and development of new social, economic and political forms of organization is manifest. Any local example for the success of different forms of social organization (that is not an abstract theory but a lived experience) can create a sense of opening of the enclosure.

For, as Graeber underlines, "the moment there appears to be any sense of opening, the imagination will immediately spring forth." ${ }^{32}$ This imagination has the potential to animate an increasing part of the population of (Western) societies who have currently opted to be "idiots" (in the Arendt sense) or who have been outsourced into passivity (e.g. the unemployed youth in Southern Europe). But as pervious social and art movements have shown, this energy can be also diffused if it lacks a utopian vision. Art and science can contribute to this process by not reproducing the enclosure in their practice and by including a utopian dimension into the generation of knowledge. Mumford declares that: "Though the paralysis of the arts and sciences our contemporary programs for revolution and reform have done very little to lift our heads over the disorderly and bedraggled environments in which we conduct our daily business." 33 Although the idea of revolution has henceforth found its justified place in the advertising world (or in the apocalyptic imagination), the idea of utopian political transformation is certainly only present in the "bedraggled" margins of arts and sciences. Hence the "paralysis" and the sense of not lifting the heads high enough.

Although Thomas More was most likely not aware that he lived at the beginning of a world system that, in Wallerstein's interpretation, lasted for more than 500 years, he developed utopian visions as a result of the diffuse feeling of historical transformation. If we accept Wallerstein's premise, then the importance of the free will factor and therefore of political agency is of foremost importance in shaping the future. Being enclosed in the Ho(b)lraum-society there is now a possibility to open the "takeaway lacuna" with ideas that at least potentially could lead to a different future that is not imprisoned in "end" or "post" metaphors.

\section{BIBLIOGRAFÍA}

Arendt, Hannah, The Human Condition (Chicago: The University of Chicago Press, 1998).

Bloch, Ernst, A Philosophy of the Future (New York: Herder and Herder, 1970).

\footnotetext{
32 Graeber, Revolutions in Reverse: 33.

${ }^{33}$ Mumford, The Story of Utopias: 180.
} 
—, Tendenz-Latenz-Utopie (Frankfurt: Suhrkamp, 1978).

Goodwin, Barbara, and Tyler, Keith, The Politics of Utopia: A Study in Theory and Practice (London: Hutchinson, 1981).

Graeber, David, Debt: The first 500 Years (New York: Melville House, 2012).

—, Revolutions in Reverse: Essays on Politics, Violence, Art and Imagination (New York: Minor Compositions, 2011).

Haiven, Max, and Khasnabish, Alex, The Radical Imagination: Social Movement Research in the Age of Austerity (London: Zed, 2014).

Hoyer, Dirk, "The Possibility of Another Island: Utopian Discourse in the Age of Dystopia", Antae 4-1 (2017): 25-37.

Judt, Tony, Ill Fares the Land (London: Penguin, 2010).

Levitas, Ruth, The Concept of Utopia (Witney: Peter Lang, 2011).

Lilla, Mark, The Shipwrecked Mind, On Political Reaction (New York: New York Review Books, 2016).

Mumford, Lewis, The Story of Utopias (New York: Boni and Liveright, 1922).

Pohl, Nicole, "Utopia Matters", Spaces of Utopia 7 (2009): 1-14.

Wallerstein, Immanuel, Utopistics, Or Historical Choices of the Twenty-first Century (New York: The New Press, 1998).

Wright, Eric Olin, Envisioning Real Utopias (London: Verso, 2010).

Recibido: 10 de abril de 2017

Aprobado: 5 de octubre de 2017 